\title{
Gambaran Status Gizi pada Balita di Puskesmas Karang Harja Bekasi Tahun 2019
}

\author{
Nurshifa Eka Putri*, Sadiah Achmad \\ Prodi Pendidikan Kedokteran, Fakultas Kedokteran, Universitas Islam \\ Bandung, Indonesia. \\ **nurshifaekaputri99@gmail.com
}

\begin{abstract}
Humans, especially toddlers, need good nutritional status. Nutritional status is the state of the body due to food consumption and use of nutrients, which is defined as the balance of energy that is entered and released by the body. The health profile of Bekasi Regency in 2017 shows that there are $3.88 \%$ of children under five with malnutrition status and $0.04 \%$ with malnutrition status. And $2.91 \%$ of children under five with more nutrition. This study aims to determine the nutritional status of children under five at Puskesmas Karang Harja Bekasi in 2019. This study uses a descriptive research method with a cross sectional design that measures variables as well as to determine the nutritional status of children. Sampling of this research is a total sampling technique from recording data reporting months of weighing toddlers aged 12-60 months at Puskesmas Karang Harja Bekasi in 2019. This research was conducted from September to December 2020. The results of this study indicate that children under five at Puskesmas Karang Harja Bekasi in 2019 as many as 902 people, 771 people with good nutrition $(85.5 .3 \%), 62$ people (7.9\%) with good nutrition, 59 people $(6.5 \%) \%$ malnutrition and ten people $(1.1 \%)$ ) malnutrition. This study concluded that the nutritional status of children under five was mostly good. However, there are still children with low nutritional status, so it should be noted that there are still many malnourished children under five in Indonesia.
\end{abstract}

\section{Keywords: Nutritional Status, Toddler.}

Abstrak. Manusia khususnya balita membutuhkan status gizi yang baik. Status gizi adalah keadaan tubuh sebagai akibat dari konsumsi makanan dan penggunaan gizi, yang didefinisikan sebagai keseimbangan energi yang masuk dan dilepaskan oleh tubuh. Profil kesehatan Kabupaten Bekasi tahun 2017 menunjukkan terdapat $3,88 \%$ balita dengan status gizi buruk dan 0,04\% dengan status gizi buruk. Dan 2,91\% balita dengan gizi lebih. Penelitian ini bertujuan untuk mengetahui status gizi balita di Puskesmas Karang Harja Bekasi tahun 2019. Penelitian ini menggunakan metode penelitian deskriptif dengan desain cross sectional yang mengukur variabel dan untuk mengetahui status gizi balita. Pengambilan sampel dalam penelitian ini adalah teknik total sampling dari pencatatan data pelaporan bulan penimbangan balita usia 12-60 bulan di Puskesmas Karang Harja Bekasi tahun 2019. Penelitian ini dilakukan pada bulan September hingga Desember 2020. Hasil penelitian ini menunjukkan bahwa balita di Puskesmas Karang Harja Bekasi tahun 2019 sebanyak 902 orang, gizi baik 771 orang $(85.5,3 \%)$, gizi baik 62 orang $(7,9 \%)$, gizi baik 59 orang $(6,5 \%) \%$ dan gizi buruk sepuluh orang $(1,1 \%)$ ) malnutrisi. Studi ini menyimpulkan bahwa status gizi balita sebagian besar baik. Namun demikian, masih terdapat balita dengan status gizi rendah, sehingga perlu diperhatikan bahwa masih banyak balita gizi buruk di Indonesia.

Kata Kunci: Status Gizi, Balita. 


\section{A. Pendahuluan}

Artikel ini menggambarkan status gizi balita di Puskesmas Karang Harja Bekasi. Masalah gizi pada dasarnya merupakan refleksi konsumsi zat gizi yang belum mencukupi kebutuhan tubuh. Seseorang akan mempunyai status gizi baik, apabila asupan gizi sesuai dengan kebutuhan tubuhnya. Asupan gizi yang kurang dalam makanan, dapat menyebabkan kekurangan gizi, sebaliknya orang yang asupan gizinya berlebih akan menderita gizi lebih. Jadi status gizi adalah gambaran individu sebagai akibat dari asupan gizi sehari-hari.

Status gizi dapat diketahui melalui pengukuran beberapa parameter, kemudian hasil pengukuran tersebut dibandingkan dengan standar atau rujukan. Peran penilaian status gizi bertujuan untuk mengetahui ada tidaknya status gizi yang salah. Penilaian status gizi menjadi penting karena dapat menyebabkan terjadinya kesakitan dan kematian terkait dengan status gizi. Oleh karena itu dengan diketahuinya status gizi, dapat dilakukan upaya untuk memperbaiki tingkat kesehatan pada masyarakat.

Mengkonsumsi makanan yang seimbang dan bergizi, termasuk biji-bijian, kacangkacangan, buah, sayuran, dan sumber pangan hewani merupakan salah satu cara penting untuk meningkatkan kesehatan, dan menjaga sistem kekebalan tubuh. Pentingnya mengkonsumsi makanan sehat dan membatasi makanan yang akan berakibat terhadap kelebihan berat badan dan obesitas serta meningkatkan risiko penyakit tidak menular, masalah gigi dan kesehatan. Kekurangan salah satu zat gizi dapat menyebabkan kekurangan zat gizi lainnya. Sebagai contoh kekurangan zat besi, magnesium dan zinc dapat menyebabkan anoreksia yang akan berakibat kepada tidak terpenuhinya zat gizi yang lain seperti protein. Kekurangan protein dapat mengganggu tumbuh kembang anak, tidak terpenuhinya zat gizi juga berdampak pada perkembangan otak dan kapasitas intelektual di masa pertumbuhannya yang menyebabkan penurunan kecerdasan. Apabila asupan zat gizi yang tidak adekuat terus berlanjut dan semakin buruk maka dapat menyebabkan kematian pada anak.

Tantangan global lain yang masih dihadapi oleh beberapa negara di dunia adalah angka kematian balita yang masih cukup tinggi. Pada tahun 2018 UNICEF mencatat bahwa anak dengan gizi lebih meningkat antara 10 hingga 12 kali lipat secara umum. Kemudian menurut WHO terdapat anak usia di bawah 5 tahun sekitar 41 juta gizi lebih. Serta Menurut Global Nutrition Report anak dengan gizi lebih mempengaruhi 40,1 juta sekitar 5,9\% anak di bawah usia 5 tahun. Pada tahun 2012 di Lebanon dan Yordania menunjukan bahwa prevalensi gizi kurang antara 5,3\% dan 14,4\%. Kemudian untuk gizi lebih di temukan berkisar antara 4,4\% di Yordania dan 11,9\% di Lebanon mencapai setinggi 16,8\% di beberapa wilayah Saudi Arabia. Terdapat masalah gizi di Bali pada tahun tahun 2017 menunjukan kasus gizi buruk sekitar 8,6\%.

Lebih dari 200 juta anak usia di bawah 5 tahun di negara berkembang, lebih dari sepertiga gagal untuk mencapai potensi perkembangan. Faktor risiko yang memengaruhi perkembangan anak di negara berkembang adalah kesehatan yang buruk, gizi buruk, defisiensi mikronutrien, serta stimulasi dan pengasuhan dalam belajar kurang selama periode penting tersebut.1,2 Potensi perkembangan pada anak yang tidak terpenuhi dapat menyebabkan kesulitan dalam menempuh pendidikan seperti terlambat masuk sekolah, prestasi yang buruk, dan keterbatasan tersebut menghambat kesuksesan di kemudian hari.12 Prevalensi status gizi (BB/U) pada anak balita di Indonesia menurut Riskesdas 2018, gizi buruk sebanyak 3,9\%, gizi kurang sebanyak $13,4 \%$, gizi baik sebanyak $79,2 \%$, sedangkan gizi lebih sebanyak $3,1 \%$. Sedangkan prevalensi status gizi (BB/U) pada anak balita di Jawa Barat menurut Riskesdas 2018, gizi buruk sebanyak 2,6\%, gizi kurang 10,6\%, gizi baik sebanyak $84,3 \%$, sedangkan gizi lebih sebanyak 2,5\%. Menurut Profil Kesehatan Kabupaten Bekasi pada tahun 2017 terdapat 3,88\% balita berstatus gizi kurang dan 0,04\% berstatus gizi buruk. Dan Sebesar 2,91\% balita dengan gizi lebih. Kemudian Menurut laporan Hasil Riset Kesehatan Dasar (RISKESDAS) Kabupaten Bekasi tahun 2018 bahwa terdapat sebanyak 3,10\% balita dengan status gizi buruk, sebanyak $11,83 \%$ gizi kurang, kemudian sebanyak $88.82 \%$ gizi baik, serta sebanyak $4,25 \%$ gizi lebih. Pada tahun 2018 banyak ditemukan kasus gizi buruk di wilayah Puskesmas Karang Harja yaitu sebanyak 3 kasus dan balita gizi kurang sebanyak 33 Balita.

Berdasarkan uraian diatas, maka penulis tertarik untuk melakukan penelitian tentang Gambaran Status Gizi Pada Balita di Puskesmas Karang Harja Bekasi. 


\section{B. Metode Penelitian}

Penelitian ini menggunakan metode penelitian deskriptif dengan rancangan cross sectional yang mengukur variabel pada waktu bersamaan untuk mengetahui gambaran Status gizi pada balita di puskesmas karang harja bekasi tahun 2019. Metode pengambilan sampel pada penelitian ini adalah dengan teknik total sampling dari seluruh balita usia 12-60 bulan di puskesmas karang harja bekasi tahun 2019 yang memenuhi kriteria inklusi. Kemudian Kriteria Inklusi dalam penelitian ini adalah anak balita berusia 12-60 bulan yang bertempat tinggal tetap di wilayah kerja puskesmas karang harja dengan data tercatat lengkap pada laporan pencatatan bulan penimbangan balita. Didapatkan jumlah balita sebanyak 902 orang yang sesuai dengan kriteria inklusi.

Penelitian ini telah mendapat persetujuan etik oleh Komite Etik Penelitian Kesehatan Fakultas Kedokteran Universitas Islam Bandung dengan nomor : 113/KEPKUnisba/XII/2020.

\section{Hasil Penelitian dan Pembahasan}

Dari hasil penelitian yang dilakukan didapatkan hasil sebagai berikut :

Tabel 1. Karakteristik Responden (Laki-Laki, Perempuan)

\begin{tabular}{|l|c|c|}
\hline Jenis kelamin & Jumlah & $\%$ \\
\hline Laki-laki & 562 & 62.3 \\
\hline Perempuan & 340 & 37.7 \\
\hline Total & 902 & 100.0 \\
\hline
\end{tabular}

Berdasarkan tabel di atas diketahui bahwa dari 902 balita di Puskesmas Karang Harja Bekasi Tahun 2019, terdapat sebanyak 562 orang dengan presentase sebesar (62.3\%) berjenis kelamin laki-laki dan 340 orang dengan presentase sebesar $(37.7 \%)$ berjenis kelamin perempuan.

Tabel 2. Gambaran Berat Badan Menurut Umur (Gizi Baik, Gizi Kurang, Gizi Lebih, Gizi Buruk)

\begin{tabular}{|l|c|c|}
\hline $\begin{array}{c}\text { Berat Badan Menurut } \\
\text { Umur }\end{array}$ & Jumlah & $\%$ \\
\hline Gizi Baik & 771 & 85.5 \\
\hline Gizi Kurang & 62 & 6.9 \\
\hline Gizi Lebih & 59 & 6.5 \\
\hline Gizi Buruk & 10 & 1.1 \\
\hline \multicolumn{1}{|c|}{ Total } & 902 & 100.0 \\
\hline
\end{tabular}

Berdasarkan tabel di atasdiketahui bahwa dari 902 balita di Puskesmas Karang Harja Bekasi Tahun 2019, terdapat sebanyak 771 orang dengan presentase sebesar $(85.5 \%)$ dengan kategori gizi baik, kemudian sebanyak 62 orang dengan presentase sebesar $(6.9 \%)$ dengan kategori gizi kurang, sebanyak 59 orang dengan presentase sebesar $(6.5 \%)$ dengan kategori gizi lebih, serta 10 orang dengan presentase sebesar $(1.1 \%)$ dengan kategori gizi buruk.

Hasil penelitian berdasar atas data laporan pencatatan bulan penimbangan balita bahwa, sebagian besar balita dikategorikan memiliki status gizi baik. Kemudian pada urutan kedua terbanyak yaitu balita yang dikategorikan memiliki status gizi kurang. Selanjutnya adalah balita yang dikategorikan memiliki status gizi lebih dan terakhir adalah balita yang dikategorikan status gizi buruk. Hal ini di karenakan Setiap orang mempunyai status gizi yang berbeda, terkait dengan asupan gizi dan kebutuhannya. Jika asupan gizi dengan kebutuhan tubuh seimbang, maka akan menghasilkan status gizi baik, sebaliknya jika antara asupan gizi dengan kebutuhan tubuh tidak seimbang akan menimbulkan masalah status gizi. 
Berdasarkan hasil laporan pencatatan bulan penimbangan balita yang didapatkan dengan menggunakan perhitungan rasio berat badan/usia bahwa, terdapat sebagian besar balita dikategorikan memiliki status gizi baik dengan 771 balita dan persentase 85,5\%. Kemudian pada urutan kedua terbanyak yaitu balita yang dikategorikan memiliki status gizi kurang dengan 62 balita dan persentase sekitar 6,9\%. Selanjutnya adalah balita yang dikategorikan memiliki status gizi lebih dengan 59 balita dan persentase 6,5\% serta terakhir adalah sebanyak 10 balita yang dikategorikan termasuk dalam kategori status gizi buruk dengan presentase sebesar 1,1\%.

Status gizi seseorang tergantung dari asupan gizi dan kebutuhannya, jika antara asupan gizi dengan kebutuhan tubuhnya seimbang, maka akan menghasilkan status gizi baik. Kebutuhan asupan gizi setiap individu berbeda antar individu, hal ini tergantung pada usia, jenis kelamin, aktivitas, berat badan, dan tinggi badan. Kelebihan asupan gizi dibandingkan dengan kebutuhan akan disimpan dalam bentuk cadangan dalam tubuh. Misal seseorang yang kelebihan asupan karbohidrat yang mengakibatkan glukosa darah meningkat, akan disimpan dalam bentuk lemak dalam jaringan adiposa tubuh. Sebaliknya seseorang yang asupan karbohidratnya kurang dibandingkan kebutuhan tubuhnya, maka cadangan lemak akan diproses melalui proses katabolisme menjadi glukosa darah kemudian menjadi energi tubuh. Kemudian anak yang berat badannya kurang disebabkan oleh asupan gizinya yang kurang, hal ini mengakibatkan cadangan gizi tubuhnya dimanfaatkan untuk kebutuhan dan aktivitas tubuh. Kekurangan asupan gizi dari makanan dapat mengakibatkan penggunaan cadangan tubuh, sehingga dapat menyebabkan kemerosotan jaringan. Kemerosotan jaringan ini ditandai dengan penurunan berat badan atau terhambatnya pertumbuhan tinggi badan.

\section{Keterbatasan Penelitian}

Dalam melakukan penelitian ini peneliti mengalami beberapa keterbatasan dalam melakukan penelitian. Diantaranya, variabel ini merupakan variabel tunggal, sehingga hasil penelitian terbatas pada tingkat gambaran status gizi balita.

\section{Kesimpulan}

Simpulan penelitian ini balita di Puskemas Karang Harja Bekasi mayoritas adalah laki-laki dengan status gizi status gizi baik.

\section{Daftar Pustaka}

[1] Harjatmo T.P, Par'i. H.M, Wiyono. S. Bahan ajar gizi \& penilaian status gizi. Kementerian kesehatan republik indonesia. 2017 Okt. hlm. 44.

[2] Kementerian kesehatan. Riset kesehatan dasar trahun 2018. Pernyataan bersama tentang ketahanan pangan dan gizi dalam konteks pandemi COVID-19 di Indonesia. United Nation Indonesia. 2020 Mei 14. Diadaptasi dari "FAO, UNICEF, WFP, and WHO Joint statement on nutrition in the context of the COVID-19 pandemic in Asia and The Pacific", 2020 Apr 17.

[3] Hardiansyah, Supariasa IDN. Penelitian dan wirausaha gizi. Edisi Ke-1. Jakarta: Penerbit buku kedokteran EGC; 2016. hlm. 3-504.

[4] Eric. the state of the world's children 2019. Childrren, food and nutrition growing well in a changing world. UNICEF.

[5] World Health Organization (WHO). Malnutrition 2019. Available from: https://www.who.int/newsroom/fact-sheets/detail/malnutrition.

[6] Report G.N. 2020 Global nutrition report: Action on equity to end malnutrition.Britsol, UK : depelovement initiatives. The global nutrition report's independent expert group. 2020.

[7] Nasreddine L. A. Kassis, et al. Nutritional status and dietary intakes of children amid the nutrition transition : the case of the eastern Mediterranean region. Nutritional research. 2018:12-17.

[8] Kemenkes R.I. Hasil utama riset kesehatan dasar 2018. Kementrian Kesehatan Republik Indonesia. 2018. 
[9] Kementerian kesehatan R.I. Laporan Provinsi Jawa Barat, RISKESDAS 2018. Lembaga penerbit badan penelitian dan pegembangan kesehatan. 2019.

[10] Dinkes kaupaten bekasi. Profil kesehatan UPTD puskesmas karang harja tahun 2019. Dinas kesehatan kabupaten bekasi UPTD puskesmas karang harja. 2019. hlm. 4 -26.

[11] Rochmawati, Marlenywati, Waliyo E. Gizi kurus (WASTING) pada balita di wilayah kerja Puskesmas Kota Pontianak. Jurnal vokasi Kesehatan. 2016 Jul;2(2):132-138.

[12] Ulfah. E, Rahayuningsih S.E, Herman H. Asuhan Nutrisi dan Stimulasi dengan Status Pertumbuhan dan Perkembangan Balita Usia 12-36 Bulan. GMHC. 2018;6(1):12-20. 